\title{
Differential tissue-specific protein markers of vaginal carcinoma
}

\author{
K Hellman*,1, AA Alaiya ${ }^{*, 2}$, S Becker ${ }^{3}$, M Lomnytska $^{4}$, K Schedvins ${ }^{5}$, W Steinberg ${ }^{6}$, A-C Hellström', \\ $S$ Andersson ${ }^{4}, \cup$ Hellman ${ }^{7}$ and $G$ Auer $^{3}$
}

'Department of Gynaecologic Oncology, Radiumhemmet, Karolinska University Hospital, SE-17I 76 Stockholm, Sweden; ${ }^{2}$ Proteomics Unit, Stem Cell Therapy Program, King Faisal Specialist Hospital and Research Center, Box 3354, (MBC\#03), 1 I 21 I, Riyadh, Saudi Arabia; ${ }^{3}$ Unit of Cancer Proteomics, Department of Oncology and Pathology, Karolinska Institute and Hospital, SE- 17176 Stockholm, Sweden; ${ }^{4}$ Institute for Clinical Science, Department of Obstetrics and Gynaecology, Karolinska University Hospital, Huddinge, Karolinska Institute, SE-I 4 I 86 Stockholm, Sweden; ${ }^{5}$ Department of Gynaecology, Karolinska University Hospital, SE-17I 76 Stockholm, Sweden; ${ }^{\circ}$ Institution of Cytological Diagnosis (Kloster-Paradiese), Im Stiftsfeld, I59494 Soest, Germany; ' Ludwig Institute for Cancer Research Ltd, Uppsala University, Box 595, SE-751 24, Uppsala, Sweden

The objective was to identify proteins differentially expressed in vaginal cancer to elucidate relevant cancer-related proteins. A total of 16 fresh-frozen tissue biopsies, consisting of 5 biopsies from normal vaginal epithelium, 6 from primary vaginal carcinomas and 5 from primary cervical carcinomas, were analysed using two-dimensional gel electrophoresis (2-DE) and MALDI-TOF mass spectrometry. Of the 43 proteins identified with significant alterations in protein expression between non-tumourous and tumourous tissue, 26 were upregulated and 17 were downregulated. Some were similarly altered in vaginal and cervical carcinoma, including cytoskeletal proteins, tumour suppressor proteins, oncoproteins implicated in apoptosis and proteins in the ubiquitin-proteasome pathway. Three proteins were uniquely altered in vaginal carcinoma (DDX48, erbB3-binding protein and biliverdin reductase) and five in cervical carcinoma (peroxiredoxin 2, annexin A2, sarcomeric tropomyosin kappa, human ribonuclease inhibitor and prolyl-4hydrolase beta). The identified proteins imply involvement of multiple different cellular pathways in the carcinogenesis of vaginal carcinoma. Similar protein alterations were found between vaginal and cervical carcinoma suggesting common tumourigenesis. However, the expression level of some of these proteins markedly differs among the three tissue specimens indicating that they might be useful molecular markers.

British Journal of Cancer (2009) I 00, I303-1314. doi:I0.1038/sj.bjc.6604975 www.bjcancer.com

Published online 24 March 2009

(c) 2009 Cancer Research UK

Keywords: vaginal carcinoma; cervical carcinoma; proteomics

Primary carcinoma of the vagina (PCV) accounts for approximately $1-2 \%$ of all gynaecological malignancies and predominantly affects postmenopausal women (Pettersson, 1999; Beller et al, 2006). However, the majority (85-90\%) of malignancies arising in the vagina are metastatic lesions. Histologically most PCV cases are squamous cell carcinomas (Pettersson, 1999; Beller et al, 2006). As PCV is rare, little is known about aetiological and prognostic factors or about biological markers. The only established prognostic factor is tumour stage. It has been suggested that vaginal and cervical carcinomas share a common aetiology, because vaginal tumours tend to occur as a second primary malignancy in patients with a history of cervical dysplasia and/or neoplasia even after hysterectomy for these disorders (Choo and Anderson, 1982; Eddy et al, 1991; Kirkbride et al, 1995). Cervical squamous carcinomas are strongly associated with human papillomavirus (HPV) infection, with a prevalence of almost $100 \%$ (Bosch and Munoz, 2002). However, HPV-DNA has been identified in PCV in only about 50\% of the cases (Daling and Sherman, 1992; Hildesheim et al, 1997). Cervical carcinomas occur in younger women, usually under the age of 60 , whereas PCV is mainly found in older women. It has been proposed that PCV may develop in different ways, either through HPV-induced mutation or through

\footnotetext{
*Correspondence: Dr K Hellman; E-mail: Kristina.Hellman@ki.se or Dr AA Alaiya; E-mail: aalaiya@kfshrc.edu.sa

Received 21 November 2008; accepted 16 February 2009; published online 24 March 2009
}

other non-HPV factors that are also likely to play a role in the aetiology of PCV.

It is sometimes difficult to discriminate between PCV, cervical carcinoma and metastatic lesions, especially in patients with recurrent disease. Correct diagnosis is important for choice of therapy, prognosis and follow-up. Treatment and estimated tumour aggressiveness are still based on crude histopathological and clinical parameters, in both PCV and cervical carcinoma, resulting in individual cases of under- and over-treatment.

Increased biological knowledge of PCV and cervical carcinoma is needed to understand the molecular mechanisms of carcinogenesis and to find tumour-specific markers for diagnosis, prognosis and treatment.

Proteomic analysis provides an effective tool for understanding tumour biology and for establishing tumour-specific markers or protein profiles for certain clinical indications. Several genomic and proteomic studies have been carried out during the past decade to analyse gene expression and protein profiles for a variety of malignancies to find diagnostic, prognostic and predictive markers. 2-DE in combination with mass spectrometry has most commonly been used. Some tumour-specific markers for clinical use have been identified by proteomic studies, for example TAO1 and $\mathrm{TAO} 2$, are two effective markers for distinguishing primary lung adenocarcinoma from metastasised adenocarcinoma originating in other organs (Franzen et al, 1997; Hirano et al, 1997). These proteins were both later identified as napsin A (Chuman et al, 1999). Furthermore, cytokeratins and vimentin are used in 
the diagnosis of lung cancer and lower intestinal cancer (Cathro and Stoler, 2002; Liu et al, 2004).

Only a few proteomic studies have been conducted in cervical carcinoma (Bae et al, 2005; Choi et al, 2005; Lee et al, 2005; Lin et al, 2006), for which proteins such as annexin A2, tropomyosin 1 and 2, peroxiredoxin 2 and HSP 27 have been pointed out as potential diagnostic markers.

To date, only two studies have been carried out to investigate gene and protein expressions in vaginal carcinoma. The first study analysed the pattern of genomic imbalances in vaginal squamous cell carcinomas using comparative genomic hybridisation, which revealed that $70 \%$ of vaginal carcinomas carry relative copy number increases that map to chromosome arm 3q (Habermann et al, 2004). This pattern of genomic imbalances in PCV was strikingly similar to the one observed in cervical carcinomas (Heselmeyer et al, 1996) further strengthening the hypothesis of related aetiological pathways. Another study examined protein expression profiles using 2-DE in primary vaginal carcinoma compared with cervical carcinoma. Correlation analysis revealed high correlation between the tissue specimens. However, hierarchical cluster analysis correctly classified the samples in two groups (Hellman et al, 2004).

The purpose of this study was to identify the proteins that were differentially expressed in normal tissue and in vaginal and cervical cancer tissue by using the 2-DE protein separation technique and MALDI-TOF mass spectrometry to elucidate carcinogenetic pathways, to find out if they are functionally related and identify tumour-specific markers.

\section{MATERIALS AND METHODS}

\section{Patient tissue samples, 2-DE gel electrophoresis and image analysis}

Sixteen tissue biopsies, approximately $3 \times 3 \mathrm{~mm}$, were obtained and snap frozen. The samples consisted of five normal vaginal epithelium biopsies, as well as six primary vaginal carcinoma and five primary cervical carcinoma biopsies. This set of samples was previously described in a publication from our laboratory (Hellman et al, 2004). The histopathological characteristics of the samples are presented in Table 1.

The normal vaginal tissue samples were included as a baseline for the normal vaginal epithelium proteome and to ensure an effective comparison with vaginal cancer.

Table I Clinical and histopathological data

\begin{tabular}{|c|c|c|c|c|c|c|}
\hline No & Sample & Type of sample & Age & Stage & Histology & Grade \\
\hline I & $\mathrm{V} 24 \mathrm{~N}$ & Normal vaginal tissue & 48 & & & \\
\hline 2 & V25N & Normal vaginal tissue & 70 & & & \\
\hline 3 & V26N & Normal vaginal tissue & 56 & & & \\
\hline 4 & V37N & Normal vaginal tissue & 78 & & & \\
\hline 5 & V38N & Normal vaginal tissue & 78 & & & \\
\hline 6 & V29T & Vaginal carcinoma & 83 & । & SCC & \\
\hline 7 & V30T & Vaginal carcinoma & 54 & । & $A C$ & \\
\hline 8 & $\mathrm{~V} 3 \mathrm{IT}$ & Vaginal carcinoma & 89 & । & SCC & \\
\hline 9 & V32T & Vaginal carcinoma & 62 & । & SCC & Low \\
\hline 10 & V33T & Vaginal carcinoma & 78 & । & SCC & Medium \\
\hline | & V34T & Vaginal carcinoma & 75 & $\| \mathrm{B}$ & SCC & High \\
\hline 12 & $\mathrm{C} \times 40$ & Cervical carcinoma & 45 & $\| B$ & SCC & Low \\
\hline 13 & $C \times 41$ & Cervical carcinoma & 41 & IB2 & $A C$ & \\
\hline 14 & $\mathrm{C} \times 42$ & Cervical carcinoma & 63 & $\| A$ & $\mathrm{SCC}$ & Low \\
\hline 15 & $\mathrm{C} \times 43$ & Cervical carcinoma & 59 & IB2 & SCC & Medium \\
\hline 16 & $\mathrm{C} \times 44$ & Cervical carcinoma & 65 & $|\mathrm{~B}|$ & SCC & Medium \\
\hline
\end{tabular}

$\mathrm{SCC}=$ squamous cell carcinoma; $\mathrm{AC}=$ adenocarcinoma
The rationale for including the cervical cancer samples was to elucidate similarities and differences between cervical and vaginal cancers at the proteome level.

All tumour biopsies were obtained from patients with histopathologically confirmed diagnosis of either vaginal or cervical cancers. To guarantee sample representativity, both cytological and histological evaluations were carried out on all samples, and only in those where both examined features corresponded were included in the study as previously described (Hellman et al, 2004). Informed consent was obtained before all sampling and the Stockholm County Council ethics committee gave its approval (Dnr: $97-244)$.

Sample preparation All tissue samples were prepared according to the previously described method (Hellman et al, 2004). The proteins were extracted and solubilised in lysis buffer containing $9 \mathrm{M}$ urea (BioRad, Hercules, CA, USA) $2 \mathrm{M}$ thiourea (USB, Cleveland, OH, USA), 5\% Resolyte (BDH, Poole, UK), $65 \mathrm{~mm}$ dithiothreitol (BioRad), $1 \mathrm{~m}$ EDTA (Merck, NJ, USA), 0.5\% v/v NP-40 (Nonidet P-40; USB), 25 mm CHAPS, 0.1\% PMSF (phenylmethylsulphonyl fluoride) and $1 \%$ benzamidine (Sigma, Missouri, USA). Protein concentration was determined by the Bradford protein analysis method (Bradford, 1976).

\section{Electrophoresis}

First dimension Iso-electric Focusing (IEF): The proteins are separated according to their iso-electric point in an immobilised $\mathrm{pH}$ gradient gel (IPG strip), see below.

Second dimension Sodium dodecyl sulphate polyacrylamide gel electrophoresis (SDS-PAGE): The proteins that are focused in the immobilised $\mathrm{pH}$ gradient are further separated according to their molecular weight in a large size $10-13 \%$ gradient SDS - PAGE gel, $25 \times 20 \mathrm{~cm} \times 1.5 \mathrm{~mm}$.

Before application, the first dimension samples were diluted to $0.25 \mathrm{mg} \mathrm{ml}^{-1}$ in rehydration buffer containing urea, thiourea, CHAPS, Triton X-100 (GE Healthcare, Amersham, UK) IPG buffer 4-7 (BioRad) and a few grains of bromphenol blue (Merck, );

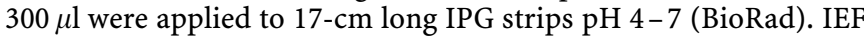
was performed in an IEF Cell (BioRad) for $22.5 \mathrm{~h}$ including rehydration until approximately $52900 \mathrm{~V}$ h were reached.

The IPG strips were subsequently treated in two steps before loading the 2-DE gradient gels. The first step was to reduce the proteins using dithiothreithol and the second was equilibration to alkylate the free SH-groups using iodoacetamide (Sigma).

The second dimension, SDS-PAGE, was performed in gradient gels with piperazinediacrylamide (PDA; BioRad) as a cross-linker, in an ISO DALT tank (GE Healthcare) with the capacity to run 10 gels simultaneously. The electrophoresis was carried out at constant power, $100 \mathrm{~V}$ using an EPS2A200 power supply (Hoefer) at $12^{\circ} \mathrm{C}$ for approximately $19 \mathrm{~h}$. After electrophoresis all gels were then incubated in fix solution, containing 30\% ethanol (Kemetyl, Haninge, Sweden) and $10 \%$ acetic acid (Sigma), and subsequently stained with silver nitrate (Merck) (Rabilloud et al, 1994). Following development, a GS-710 (BioRad) flat bed densitometer was used to scan all high-resolution gels at a resolution of $105.8 \mu \mathrm{m}$. The gels were matched to each other using PDQuest software, version 7.3.0 (BioRad). Background was subtracted and individual polypeptides quantified as p.p.m. of the total integrated optical density. Each spot was given a unique id number. All differentially expressed spots were individually examined to ensure that they were representative and were of high quality.

Excision Proteins that were statistically significantly up- or downregulated by using Mann-Whitney statistical analysis and $t$-test $(P<0.05)$, were selected for identification by mass spectrometry. Proteins were localised, excised manually, and transferred 

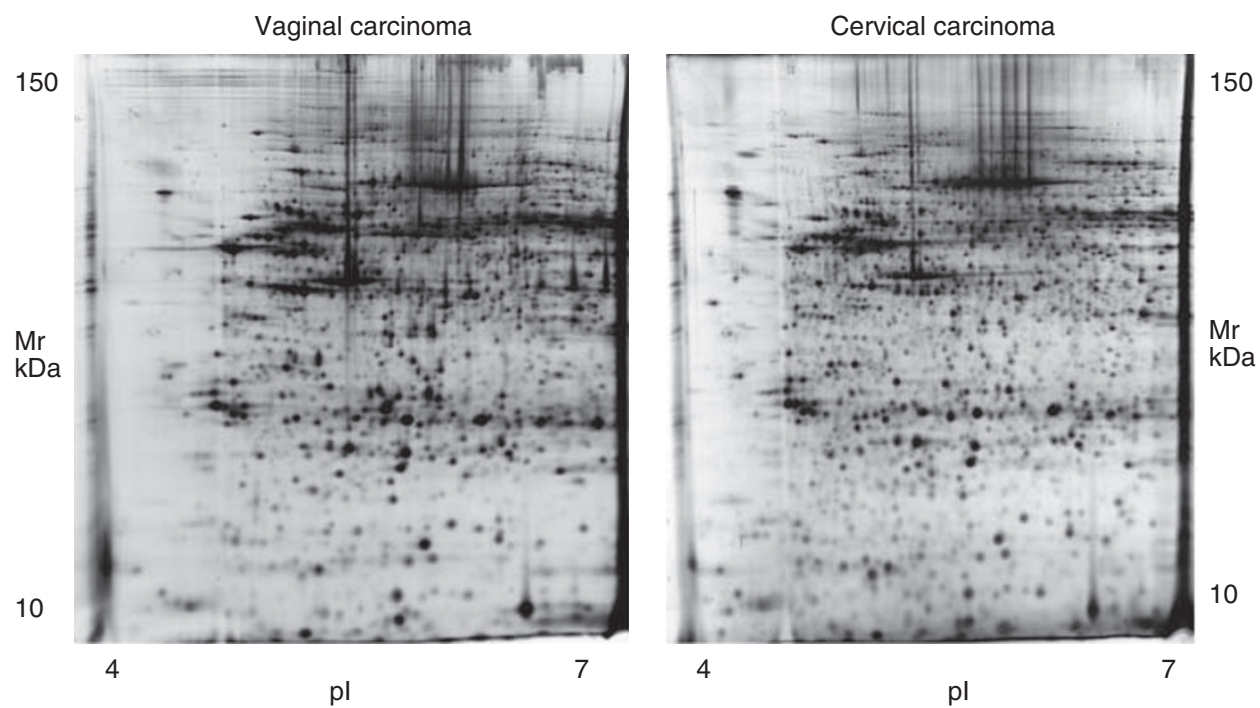

Figure I 2-DE gel images of primary vaginal and cervical carcinoma.

to sterile tubes. Some low abundant spots were pooled from different gels to increase the signal in mass spectrometric analysis. All excisions were performed in an LAF bench to minimise risk of contamination. Protective clothing, hair protection and extra arm protection were used. By maintaining these high standards keratins and other contaminants were kept low.

\section{Mass spectrometry}

In-gel digestion for peptide mass fingerprint analysis was performed manually using trypsin (Hellman, 2002), and the digests were concentrated and desalted using $\mu$ ZipTip C18 (Millipore, Billerica, MA, USA) as recommended by the manufacturer. Peptides were eluted onto the MALDI target plate in $70 \%$ acetonitrile $/ 0.1 \%$ trifluoroacetic acid containing half saturated $\alpha$ cyano-4-hydroxycinnamic acid as matrix. Peptide mass fingerprinting was performed using MALDI-TOF MS on an Ultraflex TOF/TOF III (Bruker Daltonics, Bremen, Germany).

Trypsin autolytic fragments of charged masses 842.50, 2211.10 and $3337.76 \mathrm{Da}$ were used as internal standards for spectra calibration. Data generated were screened in a protein sequence database (NCBInr, current version) using a mass tolerance $\leqslant 20$ p.p.m. Search engines used were Mascot (http://www.matrixscience.com) or ProFound (http://prowl.rockefeller.edu/prowl-cgi/). One missed cut was allowed and no restriction was made regarding species, size or $\mathrm{pI}$; that is, the search was unbiased.

The above protocol for MALDI-TOF analysis has a sensitivity of low femtomole amounts of standard 2-DE gel-separated proteins. For a positive identification using peptide mass fingerprinting, protein scores greater than 72 were considered significant $(P<0.05)$, as calculated by the MASCOT scoring algorithm. In addition, at least five matching peptides had to be found and more than $15 \%$ of the target protein's sequence had to be covered. We also considered and compared the practical and theoretical $\mathrm{pI}$ and $\mathrm{Mw}$ values of matching proteins.

\section{Data processing/data analysis}

Both quantitative and qualitative 2-DE datasets were generated from PDQuest, a 2-DE software analysis program as previously described (Hellman et al, 2004).

The differentially expressed protein spots were selected for identification.

\section{RESULTS}

Fresh-frozen tissue biopsies were subjected to 2-DE and analysed for both qualitative and quantitative differences in the expression of multiple proteins. An average total of 1373 spots were resolved on $25 \times 20 \mathrm{~cm} \mathrm{2-DE} \mathrm{gels,} \mathrm{and} \mathrm{between} 75$ and $82 \%$ of the spots were matched among all gels. Silver stain was used to visualise gel spots (Figure 1).

Using PDQuest, the protein expression pattern in the different tissue specimens (normal vaginal tissue, vaginal cancer and cervical cancer) was analysed.

Mann-Whitney statistical analysis $(P<0.05)$ revealed 67 proteins that were differentially expressed in normal vaginal tissue, vaginal cancer and cervical cancer. A similar analysis was carried out on these three groups of samples using Student's $t$-test, and 94 protein spots differed significantly. The differential analysis takes into consideration both the qualitative and quantitative changes observed between these sets of samples. Furthermore, these two separate datasets correctly classified the three groups of samples using hierarchical cluster analysis.

We excised a total of 104 spots with statistically significant variability in the expression pattern $(P<0.05)$ between normal vaginal tissue, cervical cancer and vaginal cancer for identification by MALDI-TOF mass spectrometry. One obvious limitation when working with clinical samples is getting sufficient material for detailed analysis. Therefore, a relatively large number of the protein spots in the datasets for cluster analyses could not be identified. However, 61 proteins were clearly identified and among these, 43 proteins had prominent protein expression alterations (approximately 2- to 3-fold increase/decrease) as compared with normal tissue; 26 proteins were upregulated (Table 2) and 17 downregulated (Table 3). The differential expressions of some of these proteins are shown in Figure 2.

Of the 26 upregulated proteins, 3 were upregulated in vaginal carcinoma only, compared with normal vaginal tissue and cervical cancer (DEAD box protein (DDX48 or EIF4A3), erbB3-binding protein (Ebp1) and biliverdin reductase). In cervical carcinoma, three proteins were clearly upregulated compared with vaginal carcinoma and normal vaginal tissue (thiol-specific antioxidant prot, annexin A2 and alfa-2-actin). In both cancer specimens, 20 proteins were upregulated compared with normal vaginal tissue (tyr-3-monooxygenase, nuclear chloride channel prot, apolipoprotein (2), proteasome activator hP A28 beta, RAB 1B (RAS oncogen 
Table 2 Upregulated proteins (26) in vaginal and cervical carcinoma compared to normal vaginal tissue

\begin{tabular}{|c|c|c|c|c|c|c|c|c|c|c|c|}
\hline \multirow[b]{2}{*}{$\begin{array}{l}\text { Sample } \\
\text { ID }\end{array}$} & \multirow[b]{2}{*}{ Result } & \multicolumn{3}{|c|}{$\begin{array}{l}\text { Arbitrary (relative) } \\
\text { intensity }^{\mathbf{a}}\end{array}$} & \multicolumn{2}{|c|}{ Empiric } & \multicolumn{2}{|c|}{ In silica } & \multirow[b]{2}{*}{$\begin{array}{l}\text { Accession } \\
\text { number }\end{array}$} & \multirow[b]{2}{*}{$\begin{array}{l}\text { \% Sequence } \\
\text { coverage }\end{array}$} & \multirow[b]{2}{*}{$\begin{array}{l}\text { Number of } \\
\text { matched peptides }\end{array}$} \\
\hline & & Normal & $\begin{array}{l}\text { Vaginal } \\
\text { cancer }\end{array}$ & $\begin{array}{l}\text { Cervical } \\
\text { cancer }\end{array}$ & pl & MW & pl & MW & & & \\
\hline 1107 & 14-3-3 protein theta & 2 & 4 & 3 & 4.5 & 30 & 4.7 & 28 & NP_006817 & 45 & 17 \\
\hline 1123 & Tyr-3-monooxygenase (14-3-3 zeta) & 2 & 4 & 3 & 4.8 & 30 & 4.8 & 28 & NP_0366II & 47 & 11 \\
\hline 3122 & Nuclear chloride channel prot & 2 & 4 & 4 & 5.3 & 32 & 5.0 & 27 & AAD26137 & 43 & 7 \\
\hline 4103 & Proapolipoprotein & 2 & 4 & 4 & 5.5 & 25 & 5.4 & 29 & AAA5I747 & 76 & 29 \\
\hline 4124 & Proteasome activator hP A28 beta & 2 & 4 & 4 & & & 5.4 & 28 & AAF022I 8 & 37 & 10 \\
\hline 4134 & RAB IB (RAS oncogen family) & 1 & 4 & 4 & 4.6 & 22 & 5.6 & 22 & NP_I 12243 & 46 & 8 \\
\hline 4306 & Serpin B6 (thrombin inhib) & 2 & 3 & 3 & 5.6 & 60 & 5.2 & 43 & NP_I0959| & 27 & 9 \\
\hline 5107 & Alfa-2-actin & 2 & 2 & 4 & 5.9 & 30 & 5.2 & 42 & NP_001604 & 41 & 13 \\
\hline 5114 & Apolipoprotein AI & 2 & 3 & 3 & 5.8 & 30 & 5.6 & 31 & NP_000030 & 27 & 7 \\
\hline 5121 & GST (GSTPI_HUMAN) & 2 & 4 & 4 & 5.9 & 20 & 5.5 & 23 & CAA30894 & 61 & 13 \\
\hline 7126 & PIMT & 2 & 4 & 3 & 6.4 & 20 & 6 & 25 & AAA90934 & 44 & 7 \\
\hline 7312 & Serine peptidase inhibitor (Serpin B6) & 2 & 3 & 2 & 6.2 & 65 & 5.9 & 43 & NP_l0959| & 42 & 14 \\
\hline 8114 & GST M2-2 samt MI & 2 & 4 & 3 & & & 6.0 & 26 & Gi4557966 & 71 & 16 \\
\hline 8211 & Biliverdin reductase $A$ & 2 & 4 & 2 & 6.6 & 55 & 6.1 & 34 & AAH05902 & 20 & 6 \\
\hline 8227 & Annexin A2 & I & I & 4 & 6.9 & 50 & 7.7 & 39 & AAH09564 & 18 & 6 \\
\hline 8324 & Eukar. Transl Elongation factor & 2 & 4 & 4 & 6.7 & 80 & 6.3 & 50 & NP_00I395 & 33 & 13 \\
\hline 8330 & $\begin{array}{l}\text { DEAD box (eukaryotic translation initiation } \\
\text { factor } 4 A \text {, isoform } 3 \text { (EIF4A3), eller DDX } 48 \\
\text { mRNA). }\end{array}$ & 2 & 4 & 2 & 6.7 & 80 & 6.3 & 47 & NP_055555 & 23 & 12 \\
\hline 8404 & GDP dissociation inhibitor 2 & 2 & 4 & 4 & 6.7 & 80 & 5.9 & 46 & CAll 3363 & 49 & 16 \\
\hline 8422 & $\begin{array}{l}\text { Erb } \mathrm{B} 2 \text { binding protein (erbB3 binding } \\
\text { protein } \mathrm{EBPI} \text { ) }\end{array}$ & 2 & 4 & 2 & 6.7 & 80 & 7.2 & 38 & AAD00646 & 18 & 12 \\
\hline 8511 & $\begin{array}{l}\text { Chaperonin (containing TCPI, subunit } 3 \\
\text { (gamma)) }\end{array}$ & 2 & 3 & 3 & 6.6 & 85 & 6.1 & 61 & AAH080I9 & 34 & 18 \\
\hline
\end{tabular}

I, extremely low; 2, low; 3, moderately; 4, high; ${ }^{a}$ Arbitrary (relative) intensity.

Table 3 Downregulated (17) proteins in vaginal and cervical carcinoma compared to normal vaginal tissue

\begin{tabular}{|c|c|c|c|c|c|c|c|c|c|c|c|}
\hline \multirow[b]{2}{*}{$\begin{array}{l}\text { Sample } \\
\text { ID }\end{array}$} & \multirow[b]{2}{*}{ Result } & \multicolumn{3}{|c|}{$\begin{array}{c}\text { Arbitrary (relative) } \\
\text { intensity }^{\mathbf{a}}\end{array}$} & \multicolumn{2}{|c|}{ Empiric } & \multicolumn{2}{|c|}{ In silica } & \multirow[b]{2}{*}{$\begin{array}{l}\text { Accession } \\
\text { number }\end{array}$} & \multirow[b]{2}{*}{$\begin{array}{l}\text { \%sequence } \\
\text { coverage }\end{array}$} & \multirow[b]{2}{*}{$\begin{array}{c}\text { Number of } \\
\text { matched peptides }\end{array}$} \\
\hline & & Normal & $\begin{array}{l}\text { Vaginal } \\
\text { cancer }\end{array}$ & $\begin{array}{l}\text { Cervical } \\
\text { cancer }\end{array}$ & pl & MW & pl & MW & & & \\
\hline 515 & Calreticulin & 4 & 2 & 2 & 4.4 & 95 & 4.3 & 48 & NP_004334 & 63 & 20 \\
\hline 1105 & 14-3-3 protein epsilon & 4 & 4 & 3 & 4.6 & 30 & 4.6 & 29 & NP_006752 & 57 & 16 \\
\hline 1242 & Tropomyosin 2 (beta) & 4 & I & I & 4.7 & 45 & 4.6 & 33 & NP_998839 & 58 & 24 \\
\hline 1324 & Vimentin (+keratin) & 4 & I & I & 5 & 60 & 5.1 & 53 & CAA79613 & 53 & 31 \\
\hline 1404 & Rnas inhib chain A & 4 & 4 & 1 & 4.6 & 80 & 4.7 & 52 & NP_002930 & 65 & 21 \\
\hline 1422 & Prolyl-4-hydrolase beta & 4 & 4 & I & 4.9 & 80 & 4.8 & 58 & NP_000909 & 45 & 22 \\
\hline 6439 & hnRNP HI & 3 & 4 & 2 & 6.2 & 80 & 5.8 & 49 & CAG33059 & 37 & 12 \\
\hline 6615 & Gelsolin b och a & 4 & 2 & 2 & 6 & 100 & 5.6 & 83 & NP_937895 & 36 & 24 \\
\hline 7702 & Vinculin & 4 & 2 & $2(3)$ & 6.7 & 60 & 5.6 & 88 & CAI39669 & 14 & 9 \\
\hline 7703 & Filamin & 4 & 2 & $i$ & 6.2 & 45 & 5.9 & 89 & AAHI 4654 & 22 & 12 \\
\hline
\end{tabular}

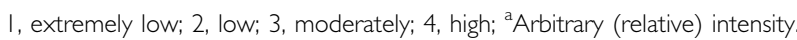

family), serpin B6 (thrombin inhib) (2), GST M2-2 as well as M1 (2), HSP 27, aldehyde dehydrogenase, (eukaryotic translation) elongation factor, GDP dissociation inhibitor 2, capping prot (actin filament), DJ-1, PIMT, chaperonin TCP1, 14-3-3 protein theta and NM23). Of the 17 downregulated proteins, 6 different proteins showed low expression in both vaginal and cervical carcinoma 

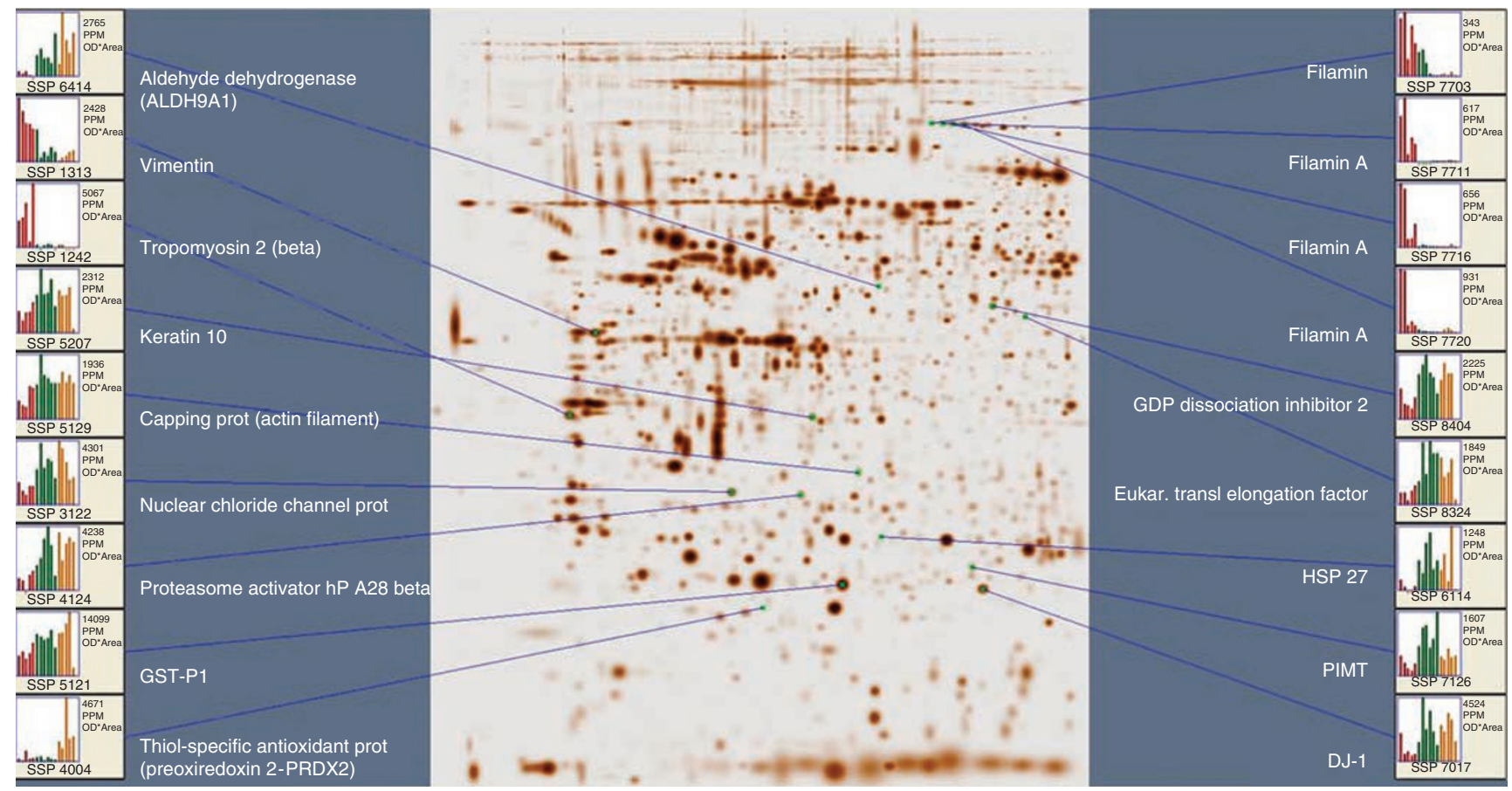

Figure 2 Global differential expression of some of the identified proteins between normal vaginal tissue, vaginal and cervical carcinoma (red = normal, green $=$ vaginal cancer and orange $=$ cervical cancer .

compared with normal vaginal tissue (calreticulin, tropomyosin 2 beta, vimentin, gelsolin, vinculin and filamin). Three proteins were distinctly downregulated in cervical carcinoma compared with vaginal cancer (sarcomeric tropomyosin kappa, Rnas inhib chain A and prolyl-4-hydrolase beta). For the distribution of proteins that were uniquely and similarly expressed in vaginal and cervical carcinoma see Figure 3. Furthermore, cluster analysis was performed using the expression patterns of some proteins that were downregulated (Figure 4) and uniquely expressed (Figure 5) in both vaginal and cervical carcinoma.

\section{DISCUSSION}

This study is the first proteomic study to analyse and identify proteins expressed in primary vaginal carcinoma and normal vaginal tissue by using MS. The expression profiles have also been compared with primary cervical carcinoma.

In all, we identified 43 proteins with significantly altered expression levels that discriminated well between non-tumourous and cancer tissue.

Thirty proteins showed similar trends of alterations in both vaginal and cervical cancer compared with normal vaginal tissue, which might indicate common carcinogenetic pathways and reflect the underlying pathogenesis to the diseases. However, three proteins were significantly altered in vaginal cancer exclusively (DEAD box, erbB3-binding protein and biliverdin reductase), and six proteins in cervical cancer (peroxiredoxin 2, annexin A2, sarcomeric tropomyosin kappa, Rnas inhib chain A and prolyl-4-hydrolase beta). These proteins may constitute valuable markers for diagnosis, prognosis or therapy, but this has to be confirmed in future studies.

Some of the proteins identified are discussed below and represent different categories involved in cellular pathways. Alterations were detected among tumour suppressor proteins, oncoproteins, proteins involved in the ubiquitin - proteasome pathway, in detoxification and antioxidation, stress-related proteins and cytoskeletal proteins. Some of these proteins have previously been described in other carcinomas, whereas others, to our knowledge, are not associated with these tumours.

\section{Tumour suppressor proteins and oncoproteins}

The DEAD box protein The DEAD box protein family of RNA helicases constitutes a large group of essential enzymes involved in all aspects of RNA metabolism, including transcription, splicing and translation (Abdelhaleem, 2004; Cordin et al, 2006). Based on their distribution patterns, members of this family are thought to be involved in different biological processes such as cellular growth and division (www.ncbi.nlm.nih.gov). Furthermore, these proteins may regulate $\mathrm{p} 21^{\text {waf1/cip } 1}$ transcription independently of p53 suggesting it may be a tumour suppressor gene (Chao et al, 2006).

The DEAD box protein 48 identified in vaginal carcinoma in this study has also been detected in pancreatic cancer and has been suggested as a potential serum marker (Xia et al, 2005).

ErbB3-binding protein 1 ErbB3-binding protein 1 (Ebp1) is a member of the family of proliferation-associated 2G4 proteins (PA2G4s) and plays a role in cellular growth and differentiation. It induces activation of the transmembrane receptor erbB3 (Kowalinski et al, 2007), which activates the ras pathway. The Ras-raf-mek pathway is the major downstream signalling pathway that emanates from all EGFR complexes. The EGFR signalling system comprises the four transmembrane proteins erbB1-erbB4, with intracellular tyrosine domains and extracellular ligand-binding domains. In vaginal cancer, the erbB3-binding protein was upregulated, indicating involvement of the ras pathway. In another study, Ebp1 overexpression resulted in downregulation of the androgen receptor leading to reduced incidence of androgen-dependent prostate tumours and slower tumour growth (Zhang et al, 2005b). To our knowledge this protein has not been described in any other carcinoma.

Ras $1 B$ Ras $1 \mathrm{~B}$ was overexpressed in both vaginal and cervical cancer cells, which further points to involvement of ras oncogenes in the carcinogenesis of these malignancies. 


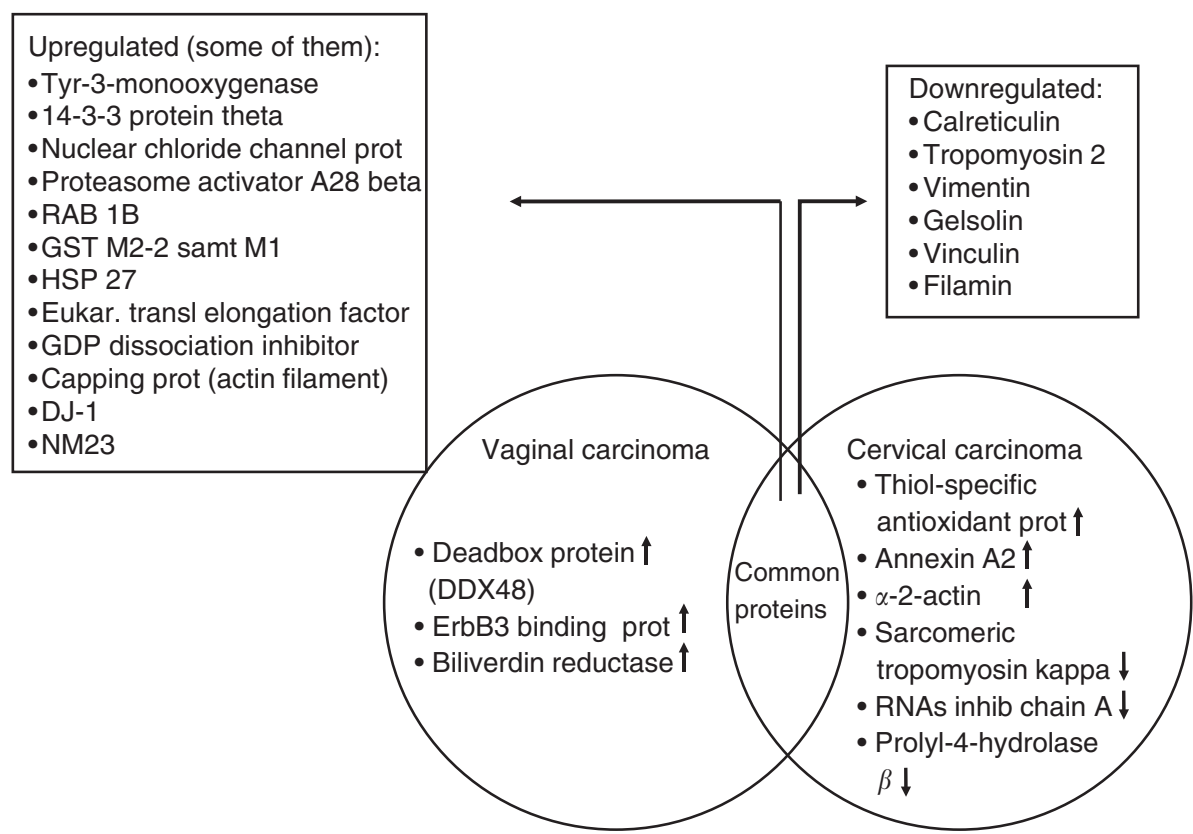

Figure 3 Venn diagram showing the proteins that were uniquely and similarly expressed in vaginal and cervical carcinomas. The arrows indicate up- or downregulation.

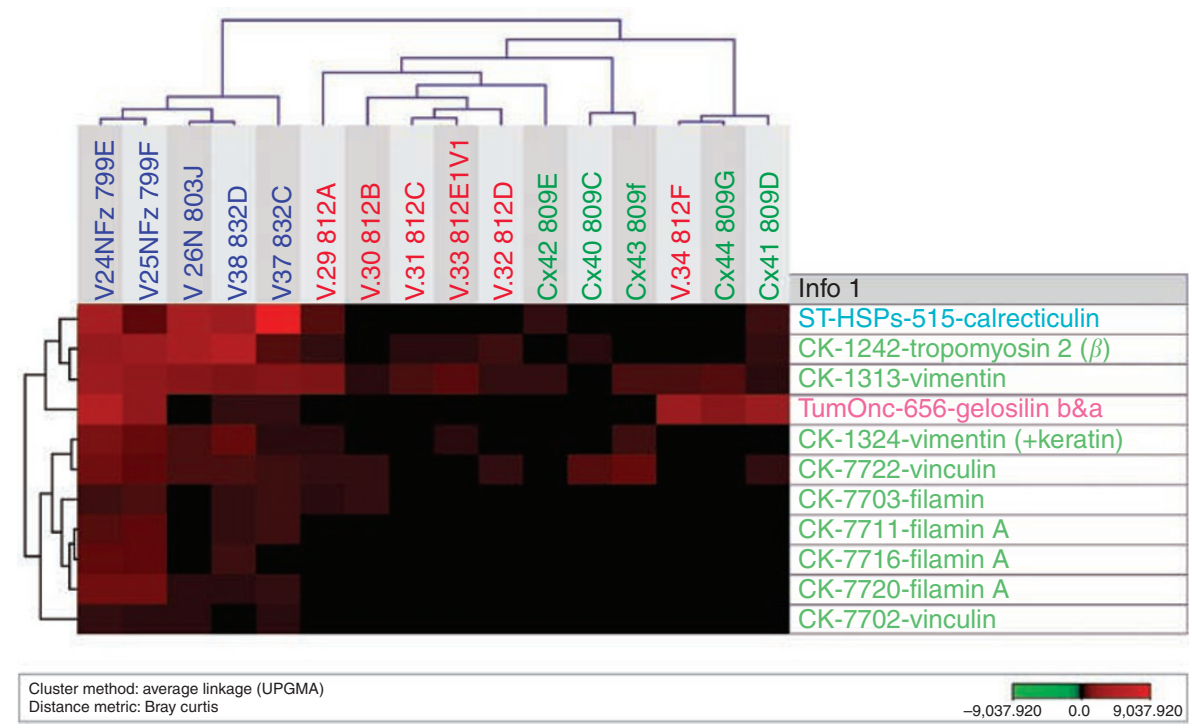

Figure 4 Cluster analysis using the expression patterns of I I identified proteins that are downregulated in both vaginal and cervical carcinoma. Note that the majority are cytoskeletal proteins.

The family of ras oncogenes has been extensively studied in human malignancies. Ras proteins play a direct causal role in human cancer and in other diseases. Mutations in the different ras oncogenes (H-Ras, $\mathrm{N}$-Ras and $\mathrm{K}$-Ras) occur in varying frequencies in different tumour types. RAS-mediated signals lead to effects on cell growth, differentiation, cycling and survival. Other cellular consequences of Ras activation include interactions with the Rho-family proteins. In gynaecological cancers, mutations of the K-Ras have been detected in endometrial $(0-47 \%)$, cervical $(0-61 \%)$ and ovarian carcinoma $(0-46 \%$; Mammas et al, 2005).

Alterations of other proteins that are supposed to function as tumour suppressors and oncoproteins were detected (14-3-3 proteins, RhoGDI2 protein, TEF1 $\delta$, DJ-1, Gelsolin and hnRNP H1).
The 14-3-3 proteins The 14-3-3 proteins belong to an important, abundant highly conserved family that interact with many cellular proteins at their phosphorylation sites and the target proteins regulate various processes such as stress response, cell-cycle control, signal transduction and apoptosis (van Hemert et al, 2001; Hermeking, 2006). Seven different isoforms of these small acidic polypeptides of $28-33 \mathrm{kDa}$ have been detected. One isoform 14-3-3 $\sigma$ (= sigma) has been directly implicated in the aetiology of human cancer. It is induced by DNA damage and appears to be required for maintaining the $\mathrm{G}_{2} / \mathrm{M}$ checkpoint in epithelial cells, and its gene is directly regulated by p53 (Hermeking, 2003). Absent or decreased expression of 14-3-3 $\sigma$ has been found in different cancers, such as vulvar cancer (Gasco et al, 2002), breast cancer (Urano et al, 2002), bladder cancer (Ostergaard et al, 1997) and neuroendocrine lung tumours (Yatabe et al, 2002). 


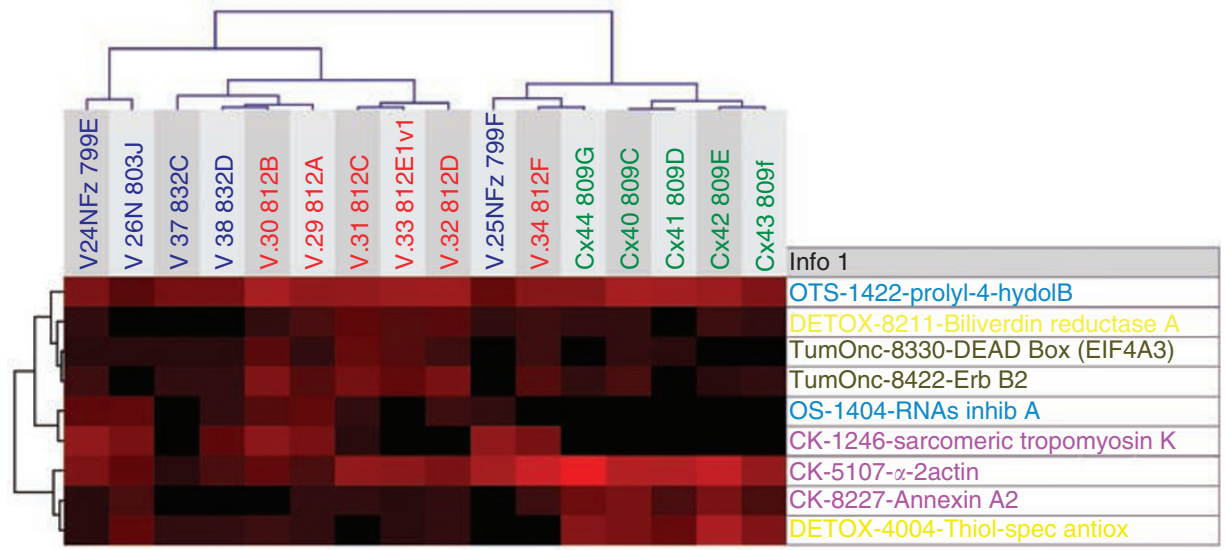

Figure 5 Cluster analysis using the expression patterns of nine identified proteins that are uniquely expressed in both vaginal and cervical carcinoma.

In this study, three other isoforms were detected: 14-3-3 theta, zeta and epsilon, which might be implicated in the genesis of vaginal and cervical cancers. Previously, 14-3-3 epsilon and zeta proteins have been shown to play a role in RAS/MAP kinase pathways (Yip-Schneider et al, 2000). Similar to our findings, downregulation of the 14-3-3 epsilon protein has been described in cervical carcinoma (Bae et al, 2005), and overexpression of 14-3-3 zeta in lung cancer cells (Qi and Martinez, 2003) and oral squamous cell carcinoma (Matta et al, 2007).

GDP dissociation inhibitors GDP Dissociation Inhibitors (RhoGDIs) are important regulators of the Rho proteins that sequester the GDP - bound Rho proteins in cytoplasm.

Rho proteins are involved in motility and metastasis of cancer cells through regulation of cell morphology and the actin cytoskeleton. RhoGDI2 has been identified as a metastasis suppressor gene, a marker of aggressive human cancer (Gildea et al, 2002). Genomic analyses of metastatic melanoma cells have shown overexpression of RhoC protein, indicating an important role of the protein in tumour invasion (Clark et al, 2000). Increased expression of Rho proteins has been detected in bladder cancer and seems to be involved in occurrence and progression of the cancer and may be valuable prognostic markers (Kamai et al, 2003).

In contrast to our results, reduced expression of RhoGDI2 has been demonstrated in bladder cancer (Theodorescu et al, 2004) and cervical SCC (Bae et al, 2005) and was associated with decreased survival in bladder cancer (Theodorescu et al, 2004) and lymph node metastasis in breast cancer (Hu et al, 2007).

The high expression of RhoGDI2 found in this study could possibly be explained by detection of these diseases at an early stage of cancer progression before downregulation of the GDP dissociation inhibitor 2 gene.

Eukaryotic translation elongation factor $1 \delta$ Eukaryotic translation elongation factor $1 \delta$ (TEF1 $\delta$ ) is a newly discovered protein (Joseph et al, 2002) that has been shown to be a protooncogene causing tumourigenetic growth in nickel-treated human bronchial epithelial cells (Lei et al, 2006). High expression of TEF1 $\delta$ was detected in NSCLC (Liu et al, 2004), which is consistent with our data.

$D J-1$ is a $20 \mathrm{kDa}$ ubiquitous cytoplasmic and nuclear oncogene product also known as PARK7. It is involved in multiple physiological processes including cancer, Parkinson's disease and male fertility (www.ncbi.nlm.nih.gov). According to a recent study overexpression of DJ-1 has protective effects on apoptosis associated with its ability to decrease the Bax level by inhibiting p53 transcriptional activity (Fan et al, 2008). High DJ-1 expression has been demonstrated in carcinomas of lung, breast and prostate (Hod, 2004; Fan et al, 2008), which is also consistent with our findings. In lung cancer this was correlated with poor clinical prognosis (Kim et al, 2005) and in breast cancer it has been associated with decreased expression of tumour suppressor phosphatase and deletion of the tensin homologue on chromosome 10 (PTEN; Kim et al, 2005).

Gelsolin Gelsolin is an $82 \mathrm{kDa}$ actin-binding protein. A gelsolin gene mutation has been found in familial amyloidosis (Haltia et al, 1992; Kamada et al, 1998). Studies have noted that overexpression of gelsolin prevent apoptosis (Ohtsu et al, 1997), whereas caspasecleaved gelsolin can cause apoptotic cell death (Kothakota et al, 1997). Thus, gelsolin seems to have a dual function, as also proposed for Bcl-2 (Kamada et al, 1998). It has been noted that cells with overexpressed gelsolin have a prolonged $S$ phase followed by a delay in $G_{2}$, suggesting that downregulation of gelsolin may lead to malignant transformation by attenuating $\mathrm{G}_{2}$ checkpoint function (Sakai et al, 1999). Similar to our results, reduced expression of gelsolin has been detected in human gastric (TMK1) and urinary bladder (UMUC2) cancer cell lines, and has further been associated with mutated TP53 and shorter survival in bladder carcinoma (Sanchez-Carbayo et al, 2007).

\section{Antioxidation and detoxification}

Several proteins involved in protein degradation, antioxidation and detoxification have been identified. Biliverdin reductase was upregulated in vaginal carcinoma, but not in cervical carcinoma. Upregulation of thiol-specific antioxidant was detected in cervical cancer, whereas prolyl-4-hydrolase beta was downregulated in cervical cancer.

Other antioxidants and detoxification proteins such as GST, Proteasome activator hP A28 beta, aldehyde dehydrogenase, serine protease inhibitor and PIMT have shown elevated expression in both vaginal and cervical cancer.

Biliverdin reductase Biliverdin reductase (BVR) is a serine/ threonine/tyrosine kinase that catalyses reduction of biliverdin to bilirubin. BVR is a zinc metalloprotein, thought to protect the cell from oxidative damage (Baranano et al, 2002; LernerMarmarosh et al, 2005). In concordance with our results, increases in biliverdin reductase expression have been detected in other 
carcinomas; renal cell (Maines et al, 1999) and hepatocellular carcinoma (Melle et al, 2007).

Thiol-specific antioxidants Thiol-specific antioxidants (TSAs), also referred to as thiol peroxidases (TPx), comprise a novel family of thiol-specific antioxidant enzymes, that provides a protective role in cells via peroxidase (Shin et al, 2005). There are five peroxiredoxins (Prx) genes. TSA $1 \mathrm{p}$ was the first peroxiredoxin to be identified and has been shown to be the major thioredoxin peroxidase in cytoplasm (Wong et al, 2002). The members of the peroxiredoxin family have diverse functions associated with various biological processes including detoxification of oxidants, cell proliferation, cell differentiation and gene expression (Fujii and Ikeda, 2002; Jang et al, 2004). Altered expression of different peroxiredoxins has been identified in several malignancies, such as in hepatocellular carcinoma (Melle et al, 2007), cervical carcinoma (Bae et al, 2005), gastric carcinoma (Jang et al, 2004), clear cell ovarian adenocarcinoma (Morita et al, 2006) and prostate carcinoma (Ahram et al, 2002). In accordance with our findings, upregulation of TSAs (peroxiredoxin 2) has been detected in HPV16 E7-expressing cervical carcinoma cells (Lee et al, 2005). Studies have also shown that overexpression of peroxiredoxin 2 protein inhibits cisplatin-induced apoptosis, thereby contributing to chemoresistance in tumour cells (Chung et al, 2001).

Prolyl-4-hydrolase beta Prolyl-4-hydrolase beta is a detoxification enzyme. Prolyl-4-hydrolase beta-isoform (P4HB) was found to be upregulated in HER-2/neu-positive breast tumours (Zhang et al, 2005a) in contrast to our findings.

The ubiquitin-proteasome pathway The ubiquitin-proteasome pathway plays a major role in non-lysosomal degradation of dysfunctional intracellular proteins in eukaryotes. Proteins that are degraded by the ubiquitin-proteasome mechanism are first conjugated to ubiquitin. Ubiquitinated proteins are recognised by the $26 \mathrm{~S}$ proteasome (Hasselgren and Fischer, 1997). Proteasomes can be activated by two different types of regulatory complexes. One is the proteasome activator hP A28 beta (Rivett et al, 1997). Alterations in ubiquitination and deubiquitination reactions have been directly implicated in the aetiology of many malignancies. Some of the natural substrates for degradation by the proteasome are oncoproteins that, if not properly removed from the cell, may induce malignant transformation (Ciechanover and Schwartz, 2004).

It has been noted that the tumour suppressor protein p53 level is extremely low in uterine cervical carcinoma tumours caused by high-risk HPV, (for example, HPVs 16 and 18). Studies have shown that the suppressor is targeted for ubiquitin-mediated degradation by the HPV oncoprotein E6 coded by high-risk strains of the virus (Scheffner and Whitaker, 2003). The viral oncoproteins exploit the ubiquitin-proteasome system to degrade and thus functionally inactivate negative cell-regulatory proteins including $\mathrm{pRb}$ and $\mathrm{p} 53$.

Upregulation of the $26 \mathrm{~S}$ proteasome subunit has been detected in HPV16 E7expressing cervical carcinoma cells (Lee et al, 2005). In accordance with our results, upregulation of proteasome activator hP A28 beta have been detected in breast cancer (Somiari et $a l, 2003$ ) and of proteasome activator complex subunit 2 in gastric cancer (Jang et al, 2004). Our results could support involvement of the ubiquitin-proteasome pathway in vaginal and cervical carcinogenesis.

Heat shock proteins Heat shock proteins (HSPs) are required for cell survival under stressful conditions and are overexpressed in a number of human cancers. HSPs have antiapoptotic properties that protects the cell from programmed cell death and they are involved in cancer immunity (Calderwood et al, 2006; Multhoff, 2006). HSP 27 is principally found in cells from tissues such as breast, uterus, cervix, placenta and skin as well as in platelets (Ciocca et al, 1993). High expression in cancer cells has been shown to correlate with prognosis and drug resistance. Increased expression of HSP 27 has been identified in ovarian (Langdon et al, 1995; Geisler et al, 1999), cervical (Bae et al, 2005) and endometrial carcinoma and correlates with good prognosis. Similarly, in this study, HSP 27 was upregulated in the cancer specimens and this may also correlate with a good prognosis, because these cases were discovered at early stage. Conversely, HSP 27 overexpression has been recognised as a negative prognostic indicator in breast (Lemieux et al, 1997) and gastric (Ciocca et al, 1993; Kapranos et al, 2002) carcinoma.

Calreticulin Calreticulin (CR) is a multifunctional calciumbinding protein present in the endoplasmic reticulum (ER) of the cell nucleus. It is an important molecular chaperone involved in 'quality control' within secretory pathways and has important regulatory functions such as modulation of steroid hormone receptors, retinoic acid receptors and regulation of cell adhesion. Increased levels of calreticulin have been reported in hepatocellular, colon, prostate and bladder carcinomas and as well as in radioresistant squamous carcinoma (Ramsamooj et al, 1995; Alaiya et al, 2000; Yoon et al, 2000; Brunagel et al, 2003; Iwaki et al, 2004).

In accordance with our results, downregulation of calreticulin has been noted in other squamous cell carcinomas, such as primary laryngeal and maxillar squamous cell carcinoma (Ogino et al, 2003, 2006).

Impaired p53 expression, function and nuclear localisation have been observed in calreticulin-deficient cells and the level of calreticulin (CRT) has been correlated with the rate of apoptosis (Mesaeli and Phillipson, 2004). Calreticulin plays a role in the control of cell adhesion via regulation of vinculin expression, which is downregulated in cells expressing reduced levels of calreticulin. Downregulation of calreticulin increases cell motility and decreases cell spreading (Opas et al, 1996).

\section{Cytoskeletal proteins}

Alterations of several cytoskeletal proteins were identified in this study. Upregulation of annexin A2 was found in cervical cancer. In both vaginal and cervical carcinoma there was a downregulation of vimentin, filamin, tropomyosin 2 (TM2 beta) as well as vinculin.

The intermediate protein family includes several hundred members (such as cytokeratin, vimentin, actin, filamin, tropomyosin) and form the cytoskeletal network together with two other filament system (microfilament and microtubules). In high-grade dysplastic cervical cells filamin, vimentin and vinculin were upregulated ( $\mathrm{Gu}$ et $\mathrm{al}, 2007)$ in contrast to the findings in cancer cells in our study.

Annexins Annexins are calcium-dependent phospholipid-binding proteins and play a role in regulating the cytoskeleton and cell motility (Benz and Hofmann, 1997). Several annexins have been implicated in the pathogenesis of benign and malignant neoplasms of different origins. In some tumours a suppressive action of annexins has been shown, whereas in other tumours annexins have been involved in progression (Bastian, 1997; Hayes and Moss, 2004). Annexin A2 has been implicated in progression, migration and metastatic potential (Gillette et al, 2004; Hayes and Moss, 2004). Upregulation of annexin A2 (in line with our results) and A5 has been described in cervical carcinoma; however, annexin A1 was downregulated suggesting different roles for these annexins in the carcinogenesis of cervical squamous cell carcinoma (Bae et al, 2005). Upregulation of annexin A2 has been reported in many malignancies, such as buccal SCC (Chen et al, 2004), pancreatic, gastric, breast and brain cancer (Hayes and Moss, 2004; Tatenhorst et al, 2006). In renal carcinoma annexin 2 has been suggested as a 
useful prognostic marker (Zimmermann et al, 2004). However, reduced or lost expression of annexin 2 has been noticed in prostate carcinoma (Liu et al, 2003a) and osteosarcoma (Gillette et al, 2004) and has been related to aggressive behaviour and metastatic potential.

Tropomyosins Tropomyosins (TMs) are actin-binding proteins. TMs isoforms and actin, are the two major structural constituents of microfilaments. The high-molecular-weight tropomyosins are thought to play a role in stabilising the organisation of actin filaments, which in turn plays an important role in the maintenance of cell shape, cell motility, and cell-cell and cellmatrix interactions (Button et al, 1995). Many TM isoforms, including tropomyosin-1 (TM1), are downregulated in transformed cells. The loss of tropomyosin expression in tumour cells may prevent proper assembly of microfilaments and, thereby contribute to the invasive and metastatic properties of cancer cells (Shah et al, 2001). In bladder carcinoma alterations in TM expression (reduced TM1, 2 and 3) seem to be an early event in bladder carcinogenesis (Pawlak et al, 2004). Similar to our findings, low expression of TM1 and TM2 has been detected in cervical carcinoma (Bae et al, 2005), of TM2 in oesophageal squamous cell carcinoma (Jazii et al, 2006) and of TM1 in breast carcinoma (Franzen et al, 1996; Raval et al, 2003). However, higher levels were found in primary breast cancer that had metastasised to the axillary lymph nodes (Franzen et al, 1996).

Alpha-2-actin Alpha-2-actin, the human aortic smooth muscle actin gene, is one of six different actin isoforms, which have been identified. Actins are highly conserved proteins that are involved in cell motility, structure and integrity. Alpha actins are a major constituent of the contractile apparatus (www.ncbi.nlm.nih.gov). In this study, high expression of alpha-2-actin was noted in cervical carcinoma.

Vimentin Vimentin is a type III intermediate filament protein that is frequently expressed in epithelial carcinomas and correlates with invasiveness and poor prognosis. Ablation of vimentin expression inhibits migration and invasion of colon and breast cancer cell lines (McInroy and Maatta, 2007) and promotes conversion of tumourigenic prostate epithelial cells into slow growing, less aggressive cells (Liu et al, 2003b). Upregulation of vimentin has been reported in prostate cancer, lung cancer and carcinosarcoma and vimentin have been used as a marker for lung cancer detection (Liu et al, 2004; Wu et al, 2007; Pardo et al, 2008; Wei et al, 2008). In colorectal tumours, increased vimentin expression correlates with the presence of oncogenic KRAS and with nuclear beta-catenin. However, corresponding liver, lymph node, brain and lung metastases did not express vimentin (Veenendaal et al, 2008), indicating other pathways in secondary colorectal tumours. Similar to the proteomic study of cervical carcinomas (Bae et al, 2005), but in contrast to the findings in other carcinomas, we found a downregulation of vimentin in both vaginal and cervical carcinoma, suggesting alternative pathways for epithelialmesenchymal transition.

Vinculin and filamin Vinculin and filamin are actin-binding proteins (ABPs) that provide structure and allow cells to be mobile. Studies have shown that filamin A integrates with beta-1 integrins to mediate cell spreading and prevent apoptosis (Kim et al, 2008). Furthermore 14-3-3 proteins bind both filamin and beta-2 integrin and induce distal signalling pathways leading to dramatic changes in the cytoskeleton, transcription and activation of integrins, which mediate adhesion (Nurmi et al, 2006). A previous study showed that filamin-A interacts with BRCA2, and lack of filamin-A expression results in increased cellular sensitivity to several DNA-damaging agents in melanoma cells (Yuan and Shen, 2001).
Vinculin is thought to function as one of several interacting proteins involved in anchoring F-actin to the membrane (www. ncbi.nlm.nih.gov).

Low levels of vinculin have been found in highly malignant neuroendocrine tumours. Therefore vinculin is thought to play a role in growth regulation of neuroendocrine tumours (Liu et al, 2007). Similarly, in this study, low levels of both vinculin and filamin were detected in vaginal and cervical carcinoma, indicating that these proteins are important for malignant transformation. There is not much data in the literature regarding vinculin and filamin expression in malignancies.

\section{Other proteins}

Rnas inhib chain A Rnas inhib chain A or human ribonuclease inhibitor (hRI) is an acid protein with a molecular weight of $50 \mathrm{kDa}$, which can inhibit the activity of pancreatic RNase (RNase A). Furthermore, RI is a highly efficient inhibitor of angiogenin, which is a member of the ribonuclease super family. Because angiogenin is an important angiogenic factor, it has been hypothesised that RI may be a latent antiangiogenic drug (Fu et al, 2005).

hRI was downregulated exclusively in cervical cancer. This finding may indicate that this protein is important for angiogenesis in cervical carcinoma and could possibly be an effective angiogenetic inhibitor in this specific type of cancer. To our knowledge this is the first time that this protein has been observed in cancer tissue.

The chloride intracellular channel The chloride intracellular channel (CLIC) gene family has been implicated in chloride ion transport within various subcellular compartments (Berryman and Bretscher, 2000).

Antisense suppression of the chloride intracellular channel family induces apoptosis, and inhibits tumour growth (Suh et al, 2005). The cell- and tissue-specific patterns of CLIC1 expression suggest it may play distinct roles in different cell types (Ulmasov et al, 2007).

In accordance with our study elevated CLIC1 levels have been reported in hepatocellular carcinoma (Huang et al, 2004) and gastric carcinoma (Chen et al, 2007) and in gastric cancer this was strongly correlated with lymph node metastasis, lymphatic invasion, perineural invasion and pathological staging indicating that CLIC1 could be a potential prognostic marker (Chen et al, 2007). Otherwise, the literature contains little data on this protein and its relationship to cancer.

This study has shown alterations and interactions of several proteins, such as proteins involved in inactivation of p53 (DEAD box, the ubiquitin-proteasome pathway, 14-3-3 protein), activation of the RAS pathway (erbB3-binding protein) and proteins implicated in apoptosis (Dj-1, Gelsolin, hnRNPH1). Alterations of cytoskeletal proteins were another important finding not previously described for these carcinomas.

In accordance with our findings in cervical carcinoma Bae et al, 2005 detected upregulation of annexin A2 and downregulation of vimentin and tropomyosins 1 and 2, which might indicate that these cytoskeletal proteins are involved in tumourigenesis and could be useful markers. Interestingly, two previously relatively unknown proteins, the angiogenic factor human ribonuclease inhibitor and the detoxification enzyme prolyl-4-hydrolase beta, were distinctly downregulated in cervical carcinoma.

In summary, the protein variations identified in this study, indicate that numerous cellular pathways are activated leading to interaction of multiple proteins during vaginal and cervical tumourigenesis, which underscore the complexity of the cellular signalling networks responsible for the development and progression of cancer. 
Some proteins were similarly altered in both vaginal and cervical carcinomas, suggesting common carcinogenetic pathways. However, certain proteins showed different levels of expression among the three tissue specimens, indicating that these could be specific tumour markers.

These data verify that proteomic analysis can provide extensive information to better understand the pathogenesis and oncogenesis of malignancies and further provide a basis to develop useful molecular markers for diagnosis, prognosis and therapy. The fact that multiple cellular pathways seem to be involved indicates that multiple proteins should be simultaneously targeted.
However, further studies are needed to confirm the results from this study.

\section{ACKNOWLEDGEMENTS}

This study was supported by the Swedish Cancer Foundation, Swedish Research Council, Medical Research Council, and Cancer Society in Stockholm, Stockholm County Council, and Swedish Labour Market Insurance. We acknowledge Dr Chaker Adra for his help in critical review of the article.

\section{REFERENCES}

Abdelhaleem M (2004) Over-expression of RNA helicases in cancer. Anticancer Res 24: 3951-3953

Ahram M, Best CJ, Flaig MJ, Gillespie JW, Leiva IM, Chuaqui RF, Zhou G, Shu H, Duray PH, Linehan WM, Raffeld M, Ornstein DK, Zhao Y, Petricoin III EF, Emmert-Buck MR (2002) Proteomic analysis of human prostate cancer. Mol Carcinog 33: 9-15

Alaiya A, Roblick U, Egevad L, Carlsson A, Franzen B, Volz D, Huwendiek S, Linder S, Auer G (2000) Polypeptide expression in prostate hyperplasia and prostate adenocarcinoma. Anal Cell Pathol 21: 1-9

Bae SM, Lee CH, Cho YL, Nam KH, Kim YW, Kim CK, Han BD, Lee YJ, Chun HJ, Ahn WS (2005) Two-dimensional gel analysis of protein expression profile in squamous cervical cancer patients. Gynecol Oncol 99: $26-35$

Baranano DE, Rao M, Ferris CD, Snyder SH (2002) Biliverdin reductase: a major physiologic cytoprotectant. Proc Natl Acad Sci USA 99: $16093-16098$

Bastian BC (1997) Annexins in cancer and autoimmune diseases. Cell Mol Life Sci 53: 554-556

Beller U, Quinn MA, Benedet JL, Creasman WT, Ngan HY, Maisonneuve P, Pecorelli S, Odicino F, Heintz AP (2006) Carcinoma of the vulva. FIGO 6th Annual Report on the Results of Treatment in Gynecological Cancer. Int J Gynaecol Obstet 95(Suppl 1): S7-S27

Benz J, Hofmann A (1997) Annexins: from structure to function. Biol Chem 378: $177-183$

Berryman M, Bretscher A (2000) Identification of a novel member of the chloride intracellular channel gene family (CLIC5) that associates with the actin cytoskeleton of placental microvilli. Mol Biol Cell 11: $1509-1521$

Bosch FX, Munoz N (2002) The viral etiology of cervical cancer. Virus Res 89: $183-190$

Bradford MM (1976) A rapid and sensitive method for the quantitation of microgram quantities of protein utilizing the principle of protein-dye binding. Anal Biochem 72: 248-254

Brunagel G, Shah U, Schoen RE, Getzenberg RH (2003) Identification of calreticulin as a nuclear matrix protein associated with human colon cancer. J Cell Biochem 89: 238-243

Button E, Shapland C, Lawson D (1995) Actin, its associated proteins and metastasis. Cell Motil Cytoskeleton 30: 247-251

Calderwood SK, Khaleque MA, Sawyer DB, Ciocca DR (2006) Heat shock proteins in cancer: chaperones of tumorigenesis. Trends Biochem Sci 31: $164-172$

Cathro HP, Stoler MH (2002) Expression of cytokeratins 7 and 20 in ovarian neoplasia. Am J Clin Pathol 117: 944-951

Chao CH, Chen CM, Cheng PL, Shih JW, Tsou AP, Lee YH (2006) DDX3, a DEAD box RNA helicase with tumor growth-suppressive property and transcriptional regulation activity of the $\mathrm{p} 21 \mathrm{waf} 1 / \mathrm{cip} 1$ promoter, is a candidate tumor suppressor. Cancer Res 66: 6579-6588

Chen CD, Wang CS, Huang YH, Chien KY, Liang Y, Chen WJ, Lin KH (2007) Overexpression of CLIC1 in human gastric carcinoma and its clinicopathological significance. Proteomics 7: 155-167

Chen J, He QY, Yuen AP, Chiu JF (2004) Proteomics of buccal squamous cell carcinoma: the involvement of multiple pathways in tumorigenesis. Proteomics 4: $2465-2475$

Choi YP, Kang S, Hong S, Xie X, Cho NH (2005) Proteomic analysis of progressive factors in uterine cervical cancer. Proteomics 5: 1481-1493

Choo YC, Anderson DG (1982) Neoplasms of the vagina following cervical carcinoma. Gynecol Oncol 14: 125-132
Chuman Y, Bergman A, Ueno T, Saito S, Sakaguchi K, Alaiya AA, Franzen B, Bergman T, Arnott D, Auer G, Appella E, Jornvall H, Linder S (1999) Napsin A, a member of the aspartic protease family, is abundantly expressed in normal lung and kidney tissue and is expressed in lung adenocarcinomas. FEBS Lett 462: 129-134

Chung YM, Yoo YD, Park JK, Kim YT, Kim HJ (2001) Increased expression of peroxiredoxin II confers resistance to cisplatin. Anticancer Res 21: $1129-1133$

Ciechanover A, Schwartz AL (2004) The ubiquitin system: pathogenesis of human diseases and drug targeting. Biochim Biophys Acta 1695: 3-17

Ciocca DR, Oesterreich S, Chamness GC, McGuire WL, Fuqua SA (1993) Biological and clinical implications of heat shock protein 27,000 (Hsp27): a review. J Natl Cancer Inst 85: $1558-1570$

Clark EA, Golub TR, Lander ES, Hynes RO (2000) Genomic analysis of metastasis reveals an essential role for RhoC. Nature 406: 532-535

Cordin O, Banroques J, Tanner NK, Linder P (2006) The DEAD-box protein family of RNA helicases. Gene 367: 17-37

Daling JR, Sherman KJ (1992) Relationship between human papillomavirus infection and tumours of anogenital sites other than the cervix. IARC Sci Publ 5: 223-241

Eddy GL, Marks Jr RD, Miller III MC, Underwood Jr PB (1991) Primary invasive vaginal carcinoma. Am J Obstet Gynecol 165: 292-296; discussion 296

Fan J, Ren H, Jia N, Fei E, Zhou T, Jiang P, Wu M, Wang G (2008) DJ-1 decreases Bax expression through repressing p53 transcriptional activity. J Biol Chem 283: $4022-4030$

Franzen B, Linder S, Alaiya AA, Eriksson E, Fujioka K, Bergman AC, Jornvall H, Auer G (1997) Analysis of polypeptide expression in benign and malignant human breast lesions. Electrophoresis 18: $582-587$

Franzen B, Linder S, Uryu K, Alaiya AA, Hirano T, Kato H, Auer G (1996) Expression of tropomyosin isoforms in benign and malignant human breast lesions. Br J Cancer 73: 909-913

Fu P, Chen J, Tian Y, Watkins T, Cui X, Zhao B (2005) Anti-tumor effect of hematopoietic cells carrying the gene of ribonuclease inhibitor. Cancer Gene Ther 12: 268-275

Fujii J, Ikeda Y (2002) Advances in our understanding of peroxiredoxin, a multifunctional, mammalian redox protein. Redox Rep 7: 123-130

Gasco M, Sullivan A, Repellin C, Brooks L, Farrell PJ, Tidy JA, Dunne B, Gusterson B, Evans DJ, Crook T (2002) Coincident inactivation of 14-33 sigma and p16INK4a is an early event in vulval squamous neoplasia. Oncogene 21: $1876-1881$

Geisler JP, Geisler HE, Tammela J, Miller GA, Wiemann MC, Zhou Z (1999) A study of heat shock protein 27 in endometrial carcinoma. Gynecol Oncol 72: $347-350$

Gildea JJ, Seraj MJ, Oxford G, Harding MA, Hampton GM, Moskaluk CA, Frierson HF, Conaway MR, Theodorescu D (2002) RhoGDI2 is an invasion and metastasis suppressor gene in human cancer. Cancer Res 62: $6418-6423$

Gillette JM, Chan DC, Nielsen-Preiss SM (2004) Annexin 2 expression is reduced in human osteosarcoma metastases. J Cell Biochem 92: $820-832$

Gu Y, Wu SL, Meyer JL, Hancock WS, Burg LJ, Linder J, Hanlon DW, Karger BL (2007) Proteomic analysis of high-grade dysplastic cervical cells obtained from ThinPrep slides using laser capture microdissection and mass spectrometry. J Proteome Res 6: 4256-4268

Habermann J, Hellman K, Freitag S, Heselmeyer-Haddad K, Hellström A-C, Shah K, Auer G, Ried T (2004) A recurrent gain of chromosome arm 3q 
in primary squamous carcinoma of the vagina. Cancer Genet Cytogenet 148: $7-13$

Haltia M, Levy E, Meretoja J, Fernandez-Madrid I, Koivunen O, Frangione B (1992) Gelsolin gene mutation - at codon 187 - in familial amyloidosis, Finnish: DNA-diagnostic assay. Am J Med Genet 42: 357-359

Hasselgren PO, Fischer JE (1997) The ubiquitin-proteasome pathway: review of a novel intracellular mechanism of muscle protein breakdown during sepsis and other catabolic conditions. Ann Surg 225: $307-316$

Hayes MJ, Moss SE (2004) Annexins and disease. Biochem Biophys Res Commun 322: $1166-1170$

Hellman K, Alaiya AA, Schedvins K, Steinberg W, Hellstrom AC, Auer G (2004) Protein expression patterns in primary carcinoma of the vagina. Br J Cancer 91: 319-326

Hellman U (2002) Peptide mapping using MALDI-TOFMS. In Silberring J, Ekman R (eds). Mass Spectrometry and Hyphenated Techniques in Neuropeptide Research, pp 259-275. Wiley: Hoboken, NJ, USA

Hermeking H (2003) The 14-3-3 cancer connection. Nat Rev Cancer 3: $931-943$

Hermeking H (2006) 14-3-3 proteins and cancer biology. Semin Cancer Biol 16: 161

Heselmeyer K, Schrock E, du Manoir S, Blegen H, Shah K, Steinbeck R, Auer G, Ried T (1996) Gain of chromosome 3q defines the transition from severe dysplasia to invasive carcinoma of the uterine cervix. Proc Natl Acad Sci USA 93: 479-484

Hildesheim A, Han C-L, Brinton LA, Nasca PC, Richarts RM, Jones RB, Ashley RL, Ziegler G, Schiller JT (1997) Sexually transmitted agents and risk of carcinoma of the vagina. Int J Gynecol Cancer 7: 251-255

Hirano T, Fujioka K, Franzen B, Okuzawa K, Uryu K, Shibanuma H, Numata K, Konaka C, Ebihara Y, Takahashi M, Kato H, Auer G (1997) Relationship between TA01 and TA02 polypeptides associated with lung adenocarcinoma and histocytological features. Br J Cancer 75: 978-985

Hod Y (2004) Differential control of apoptosis by DJ-1 in prostate benign and cancer cells. J Cell Biochem 92: 1221-1233

Hu LD, Zou HF, Zhan SX, Cao KM (2007) Biphasic expression of RhoGDI2 in the progression of breast cancer and its negative relation with lymph node metastasis. Oncol Rep 17: $1383-1389$

Huang JS, Chao CC, Su TL, Yeh SH, Chen DS, Chen CT, Chen PJ, Jou YS (2004) Diverse cellular transformation capability of overexpressed genes in human hepatocellular carcinoma. Biochem Biophys Res Commun 315: $950-958$

Iwaki H, Kageyama S, Isono T, Wakabayashi Y, Okada Y, Yoshimura K, Terai A, Arai Y, Iwamura H, Kawakita M, Yoshiki T (2004) Diagnostic potential in bladder cancer of a panel of tumor markers (calreticulin, gamma -synuclein, and catechol-o-methyltransferase) identified by proteomic analysis. Cancer Sci 95: $955-961$

Jang JS, Cho HY, Lee YJ, Ha WS, Kim HW (2004) The differential proteome profile of stomach cancer: identification of the biomarker candidates. Oncol Res 14: 491 - 499

Jazii FR, Najafi Z, Malekzadeh R, Conrads TP, Ziaee AA, Abnet C, Yazdznbod M, Karkhane AA, Salekdeh GH (2006) Identification of squamous cell carcinoma associated proteins by proteomics and loss of beta tropomyosin expression in esophageal cancer. World J Gastroenterol 12: $7104-7112$

Joseph P, Lei YX, Whong WZ, Ong TM (2002) Oncogenic potential of mouse translation elongation factor- 1 delta, a novel cadmium-responsive proto-oncogene. J Biol Chem 277: 6131-6136

Kamada S, Kusano H, Fujita H, Ohtsu M, Koya RC, Kuzumaki N, Tsujimoto Y (1998) A cloning method for caspase substrates that uses the yeast twohybrid system: cloning of the antiapoptotic gene gelsolin. Proc Natl Acad Sci USA 95: $8532-8537$

Kamai T, Tsujii T, Arai K, Takagi K, Asami H, Ito Y, Oshima H (2003) Significant association of Rho/ROCK pathway with invasion and metastasis of bladder cancer. Clin Cancer Res 9: 2632-2641

Kapranos N, Kominea A, Konstantinopoulos PA, Savva S, Artelaris S, Vandoros G, Sotiropoulou-Bonikou G, Papavassiliou AG (2002) Expression of the $27-\mathrm{kDa}$ heat shock protein (HSP27) in gastric carcinomas and adjacent normal, metaplastic, and dysplastic gastric mucosa, and its prognostic significance. J Cancer Res Clin Oncol 128: 426-432

Kim H, Sengupta A, Glogauer M, McCulloch CA (2008) Filamin A regulates cell spreading and survival via betal integrins. Exp Cell Res 314: $834-846$

Kim RH, Peters M, Jang Y, Shi W, Pintilie M, Fletcher GC, DeLuca C, Liepa J, Zhou L, Snow B, Binari RC, Manoukian AS, Bray MR, Liu FF, Tsao MS, Mak TW (2005) DJ-1, a novel regulator of the tumor suppressor PTEN. Cancer Cell 7: 263-273
Kirkbride P, Fyles A, Rawlings GA, Manchul L, Levin W, Murphy KJ, Simm J (1995) Carcinoma of the vagina - experience at the Princess Margaret Hospital (1974-1989). Gynecol Oncol 56: 435-443

Kothakota S, Azuma T, Reinhard C, Klippel A, Tang J, Chu K, McGarry TJ, Kirschner MW, Koths K, Kwiatkowski DJ, Williams LT (1997) Caspase-3generated fragment of gelsolin: effector of morphological change in apoptosis. Science 278: $294-298$

Kowalinski E, Bange G, Wild K, Sinning I (2007) Expression, purification, crystallization and preliminary crystallographic analysis of the proliferation-associated protein Ebp1. Acta Crystallogr Sect F Struct Biol Cryst Commun 63: $768-770$

Langdon SP, Rabiasz GJ, Hirst GL, King RJ, Hawkins RA, Smyth JF, Miller WR (1995) Expression of the heat shock protein HSP27 in human ovarian cancer. Clin Cancer Res 1: $1603-1609$

Lee KA, Kang JW, Shim JH, Kho CW, Park SG, Lee HG, Paik SG, Lim JS, Yoon DY (2005) Protein profiling and identification of modulators regulated by human papillomavirus $16 \mathrm{E} 7$ oncogene in $\mathrm{HaCaT}$ keratinocytes by proteomics. Gynecol Oncol 99: 142-152

Lei YX, Chen XM, Wu GR, Chen JK (2006) Abnormal expression of eukaryotic translation factors in malignant transformed human bronchial epithelial cells induced by crystalline nickel sulfide. Biomed Environ Sci 19: $53-60$

Lemieux P, Oesterreich S, Lawrence JA, Steeg PS, Hilsenbeck SG, Harvey JM, Fuqua SA (1997) The small heat shock protein hsp27 increases invasiveness but decreases motility of breast cancer cells. Invasion Metastasis 17: $113-123$

Lerner-Marmarosh N, Shen J, Torno MD, Kravets A, Hu Z, Maines MD (2005) Human biliverdin reductase: a member of the insulin receptor substrate family with serine/threonine/tyrosine kinase activity. Proc Natl Acad Sci USA 102: 7109-7114

Lin YW, Lai HC, Lin CY, Chiou JY, Shui HA, Chang CC, Yu MH, Chu TY (2006) Plasma proteomic profiling for detecting and differentiating in situ and invasive carcinomas of the uterine cervix. Int J Gynecol Cancer 16: $1216-1224$

Liu JW, Shen JJ, Tanzillo-Swarts A, Bhatia B, Maldonado CM, Person MD, Lau SS, Tang DG (2003a) Annexin II expression is reduced or lost in prostate cancer cells and its re-expression inhibits prostate cancer cell migration. Oncogene 22: $1475-1485$

Liu M, Oberg K, Zhou Y (2007) Expression and function of vinculin in neuroendocrine tumors. Tumour Biol 28: 196-204

Liu X, Wu Y, Zehner ZE, Jackson-Cook C, Ware JL (2003b) Proteomic analysis of the tumorigenic human prostate cell line M12 after microcellmediated transfer of chromosome 19 demonstrates reduction of vimentin. Electrophoresis 24: 3445-3453

Liu Y, Chen Q, Zhang JT (2004) Tumor suppressor gene 14-3-3sigma is down-regulated whereas the proto-oncogene translation elongation factor 1delta is up-regulated in non-small cell lung cancers as identified by proteomic profiling. J Proteome Res 3: 728-735

Maines MD, Mayer RD, Erturk E, Huang TJ, Disantagnese A (1999) The oxidoreductase, biliverdin reductase, is induced in human renal carcinoma $-\mathrm{pH}$ and cofactor-specific increase in activity. $J$ Urol 162: $1467-1472$

Mammas IN, Zafiropoulos A, Spandidos DA (2005) Involvement of the ras genes in female genital tract cancer. Int J Oncol 26: $1241-1255$

Matta A, Bahadur S, Duggal R, Gupta SD, Ralhan R (2007) Over-expression of 14-3-3zeta is an early event in oral cancer. BMC Cancer 7: 169

McInroy L, Maatta A (2007) Down-regulation of vimentin expression inhibits carcinoma cell migration and adhesion. Biochem Biophys Res Commun 360: $109-114$

Melle C, Ernst G, Scheibner O, Kaufmann R, Schimmel B, Bleul A, Settmacher U, Hommann M, Claussen U, Eggeling FV (2007) Identification of specific protein markers in microdissected hepatocellular carcinoma. J Proteome Res 6: 306-315

Mesaeli N, Phillipson C (2004) Impaired p53 expression, function, and nuclear localization in calreticulin-deficient cells. Mol Biol Cell 15: $1862-1870$

Morita A, Miyagi E, Yasumitsu H, Kawasaki H, Hirano H, Hirahara F (2006) Proteomic search for potential diagnostic markers and therapeutic targets for ovarian clear cell adenocarcinoma. Proteomics 6: $5880-5890$

Multhoff G (2006) Heat shock proteins in immunity. Handb Exp Pharmacol 172: $279-304$

Nurmi SM, Gahmberg CG, Fagerholm SC (2006) 14-3-3 proteins bind both filamin and alphaLbeta2 integrin in activated T cells. Ann NY Acad Sci 1090: $318-325$ 
Ogino T, Bandoh N, Hayashi T, Miyokawa N, Harabuchi Y, Ferrone S (2003) Association of tapasin and HLA class I antigen down-regulation in primary maxillary sinus squamous cell carcinoma lesions with reduced survival of patients. Clin Cancer Res 9: 4043-4051

Ogino T, Shigyo H, Ishii H, Katayama A, Miyokawa N, Harabuchi Y, Ferrone S (2006) HLA class I antigen down-regulation in primary laryngeal squamous cell carcinoma lesions as a poor prognostic marker. Cancer Res 66: $9281-9289$

Ohtsu M, Sakai N, Fujita H, Kashiwagi M, Gasa S, Shimizu S, Eguchi Y, Tsujimoto Y, Sakiyama Y, Kobayashi K, Kuzumaki N (1997) Inhibition of apoptosis by the actin-regulatory protein gelsolin. EMBO $\mathrm{J} \mathrm{16}$ : $4650-4656$

Opas M, Szewczenko-Pawlikowski M, Jass GK, Mesaeli N, Michalak M (1996) Calreticulin modulates cell adhesiveness via regulation of vinculin expression. J Cell Biol 135: 1913-1923

Ostergaard M, Rasmussen HH, Nielsen HV, Vorum H, Orntoft TF, Wolf H, Celis JE (1997) Proteome profiling of bladder squamous cell carcinomas: identification of markers that define their degree of differentiation. Cancer Res 57: $4111-4117$

Pardo J, Aisa G, Alava E, Sola JJ, Panizo A, Rodriguez-Spiteri N, Garcia JL, Torre W (2008) Primary mixed squamous carcinoma and osteosarcoma (carcinosarcomas) of the lung have a CGH mapping similar to primitive squamous carcinomas and osteosarcomas. Diagn Mol Pathol 17: $151-158$

Pawlak G, McGarvey TW, Nguyen TB, Tomaszewski JE, Puthiyaveettil R, Malkowicz SB, Helfman DM (2004) Alterations in tropomyosin isoform expression in human transitional cell carcinoma of the urinary bladder. Int J Cancer 110: $368-373$

Pettersson F (1999) Annual report on the results of treatment in gynecologic cancer. FIGO 1987-93 22, Radiumhemmet, Stockholm

Qi W, Martinez JD (2003) Reduction of 14-3-3 proteins correlates with increased sensitivity to killing of human lung cancer cells by ionizing radiation. Radiat Res 160: $217-223$

Rabilloud T, Vuillard L, Gilly C, Lawrence JJ (1994) Silver-staining of proteins in polyacrylamide gels: a general overview. Cell Mol Biol (Noisy-le-grand) 40: 57-75

Ramsamooj P, Notario V, Dritschilo A (1995) Enhanced expression of calreticulin in the nucleus of radioresistant squamous carcinoma cells in response to ionizing radiation. Cancer Res 55: 3016-3021

Raval GN, Bharadwaj S, Levine EA, Willingham MC, Geary RL, Kute T, Prasad GL (2003) Loss of expression of tropomyosin-1, a novel class II tumor suppressor that induces anoikis, in primary breast tumors. Oncogene 22: 6194-6203

Rivett AJ, Mason GG, Murray RZ, Reidlinger J (1997) Regulation of proteasome structure and function. Mol Biol Rep 24: 99-102

Sakai N, Ohtsu M, Fujita H, Koike T, Kuzumaki N (1999) Enhancement of G2 checkpoint function by gelsolin transfection in human cancer cells. Exp Cell Res 251: 224-233

Sanchez-Carbayo M, Socci ND, Richstone L, Corton M, Behrendt N, Wulkfuhle J, Bochner B, Petricoin E, Cordon-Cardo C (2007) Genomic and proteomic profiles reveal the association of gelsolin to TP53 status and bladder cancer progression. Am J Pathol 171: 1650-1658

Scheffner M, Whitaker NJ (2003) Human papillomavirus-induced carcinogenesis and the ubiquitin-proteasome system. Semin Cancer Biol 13: $59-67$

Shah V, Bharadwaj S, Kaibuchi K, Prasad GL (2001) Cytoskeletal organization in tropomyosin-mediated reversion of ras-transformation: evidence for Rho kinase pathway. Oncogene 20: 2112-2121

Shin DH, Jung S, Park SJ, Kim YJ, Ahn JM, Kim W, Choi W (2005) Characterization of thiol-specific antioxidant 1 (TSA1) of Candida albicans. Yeast 22: $907-918$

Somiari RI, Sullivan A, Russell S, Somiari S, Hu H, Jordan R, George A, Katenhusen R, Buchowiecka A, Arciero C, Brzeski H, Hooke J, Shriver C
(2003) High-throughput proteomic analysis of human infiltrating ductal carcinoma of the breast. Proteomics 3: 1863-1873

Suh KS, Mutoh M, Gerdes M, Yuspa SH (2005) CLIC4, an intracellular chloride channel protein, is a novel molecular target for cancer therapy. J Investig Dermatol Symp Proc 10: $105-109$

Tatenhorst L, Rescher U, Gerke V, Paulus W (2006) Knockdown of annexin 2 decreases migration of human glioma cells in vitro. Neuropathol Appl Neurobiol 32: $271-277$

Theodorescu D, Sapinoso LM, Conaway MR, Oxford G, Hampton GM, Frierson Jr HF (2004) Reduced expression of metastasis suppressor RhoGDI2 is associated with decreased survival for patients with bladder cancer. Clin Cancer Res 10: 3800-3806

Ulmasov B, Bruno J, Woost PG, Edwards JC (2007) Tissue and subcellular distribution of CLIC1. BMC Cell Biol 8: 8

Urano T, Saito T, Tsukui T, Fujita M, Hosoi T, Muramatsu M, Ouchi Y, Inoue S (2002) Efp targets 14-3-3 sigma for proteolysis and promotes breast tumour growth. Nature 417: $871-875$

van Hemert MJ, Steensma HY, van Heusden GP (2001) 14-3-3 proteins: key regulators of cell division, signalling and apoptosis. Bioessays 23: 936-946

Veenendaal LM, Kranenburg O, Smakman N, Klomp A, Borel Rinkes IH, van Diest PJ (2008) Differential Notch and TGFbeta signaling in primary colorectal tumors and their corresponding metastases. Cell Oncol 30: $1-11$

Wei J, Xu G, Wu M, Zhang Y, Li Q, Liu P, Zhu T, Song A, Zhao L, Han Z, Chen G, Wang S, Meng L, Zhou J, Lu Y, Wang S, Ma D (2008) Overexpression of vimentin contributes to prostate cancer invasion and metastasis via src regulation. Anticancer Res 28: $327-334$

Wong CM, Zhou Y, Ng RW, Kung Hf HF, Jin DY (2002) Cooperation of yeast peroxiredoxins Tsalp and Tsa2p in the cellular defense against oxidative and nitrosative stress. J Biol Chem 277: 5385-5394

Wu M, Bai X, Xu G, Wei J, Zhu T, Zhang Y, Li Q, Liu P, Song A, Zhao L, Gang C, Han Z, Wang S, Zhou J, Lu Y, Ma D (2007) Proteome analysis of human androgen-independent prostate cancer cell lines: variable metastatic potentials correlated with vimentin expression. Proteomics 7: $1973-1983$

Xia Q, Kong XT, Zhang GA, Hou XJ, Qiang H, Zhong RQ (2005) Proteomics-based identification of DEAD-box protein 48 as a novel autoantigen, a prospective serum marker for pancreatic cancer. Biochem Biophys Res Commun 330: 526-532

Yatabe Y, Osada H, Tatematsu Y, Mitsudomi T, Takahashi T (2002) Decreased expression of 14-3-3sigma in neuroendocrine tumors is independent of origin and malignant potential. Oncogene 21: 8310-8319

Yip-Schneider MT, Miao W, Lin A, Barnard DS, Tzivion G, Marshall MS (2000) Regulation of the Raf-1 kinase domain by phosphorylation and 14-3-3 association. Biochem J 351: $151-159$

Yoon GS, Lee H, Jung Y, Yu E, Moon HB, Song K, Lee I (2000) Nuclear matrix of calreticulin in hepatocellular carcinoma. Cancer Res 60: 1117-1120

Yuan Y, Shen Z (2001) Interaction with BRCA2 suggests a role for filamin-1 (hsFLNa) in DNA damage response. J Biol Chem 276: 48318-48324

Zhang D, Tai LK, Wong LL, Chiu LL, Sethi SK, Koay ES (2005a) Proteomic study reveals that proteins involved in metabolic and detoxification pathways are highly expressed in HER-2/neu-positive breast cancer. Mol Cell Proteomics 4: $1686-1696$

Zhang Y, Wang XW, Jelovac D, Nakanishi T, Yu MH, Akinmade D, Goloubeva O, Ross DD, Brodie A, Hamburger AW (2005b) The ErbB3binding protein Ebp1 suppresses androgen receptor-mediated gene transcription and tumorigenesis of prostate cancer cells. Proc Natl Acad Sci USA 102: $9890-9895$

Zimmermann U, Woenckhaus C, Pietschmann S, Junker H, Maile S, Schultz K, Protzel C, Giebel J (2004) Expression of annexin II in conventional renal cell carcinoma is correlated with Fuhrman grade and clinical outcome. Virchows Arch 445: 368-374 